
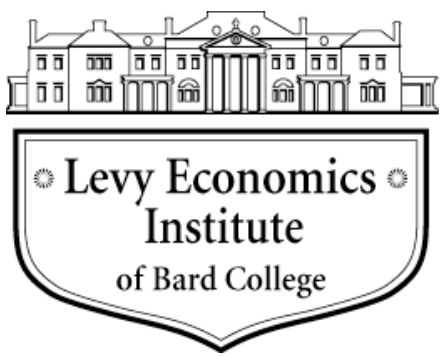

Working Paper No. 714

\title{
Managing Global Financial Flows at the Cost of National Autonomy: China and India
}

by

\author{
Sunanda Sen* \\ Levy Economics Institute of Bard College
}

April 2012

*The author thanks Dr. Jagannath Mullick and Sanmit Sengupta for their very useful help in the statistical calculations. An earlier version of this paper was presented at the FMM conference "Stabilizing an Unequal Economy? Public Debt, Financial Regulation, and Income Distribution," Berlin, October 29-30, 2010. An earlier version was also presented at a conference on globalization and economic development sponsored by the University of Kalyani, West Bengal, India, in January 2012. Comments received from the participants are gratefully acknowledged, without implicating anyone for errors or limitations in the present version.

The Levy Economics Institute Working Paper Collection presents research in progress by Levy Institute scholars and conference participants. The purpose of the series is to disseminate ideas to and elicit comments from academics and professionals.

Levy Economics Institute of Bard College, founded in 1986, is a nonprofit, nonpartisan, independently funded research organization devoted to public service. Through scholarship and economic research it generates viable, effective public policy responses to important economic problems that profoundly affect the quality of life in the United States and abroad.

\author{
Levy Economics Institute \\ P.O. Box 5000 \\ Annandale-on-Hudson, NY 12504-5000 \\ http://www.levyinstitute.org
}

Copyright (C) Levy Economics Institute 2012 All rights reserved 


\section{ABSTRACT}

The narrative as well as the analysis of global imbalances in the existing literature are incomplete without the part of the story that relates to the surge in capital flows experienced by the emerging economies. Such analysis disregards the implications of capital flows on their domestic economies, especially in terms of the "impossibility" of following a monetary policy that benefits domestic growth. It also fails to recognize the significance of uncertainty and changes in expectation as factors in the (precautionary) buildup of large official reserves. The consequences are many, and affect the fabric of growth and distribution in these economies. The recent experiences of China and India, with their deregulated financial sectors, bear this out.

Financial integration and free capital mobility, which are supposed to generate growth with stability (according to the "efficient markets" hypothesis), have not only failed to achieve their promises (especially in the advanced economies) but also forced the high-growth developing economies like India and China into a state of compliance, where domestic goals of stability and development are sacrificed in order to attain the globally sanctioned norm of free capital flows.

With the global financial crisis and the specter of recession haunting most advanced economies, the high-growth economies in Asia have drawn much less attention than they deserve. This oversight leaves the analysis incomplete, not only by missing an important link in the prevailing network of global trade and finance, but also by ignoring the structural changes in these developing economies - many of which are related to the pattern of financialization and turbulence in the advanced economies.

Keywords: Global Current Account Imbalances; Impossible Trinity; Capital Mobility; Official Reserves; Monetary Policy; National Autonomy; Efficient Market

JEL Classifications: E31, E34, E52, F42, O16, O53 
In the present paper, I draw attention to the high-growth economies of China and India, reckoned as "emerging economies" in the literature. Incidentally, both countries - and especially China — occupy center stage in the context of the prevailing global imbalances. The growth momentum in the two countries and the rapid increases in their official reserves even in the face of the global recession make these two rather special among other developing countries. However, while aspects such as those above are mentioned in the literature, what is often left out relates to the structural changes within these economies, which has a bearing not only within, but also across countries.

In the present paper, we will dwell on changes such as those above in the financial sectors of China and India that, along with most developing economies, have been exposed to the vicissitudes of global finance. In our analysis, we will try to unfold the set of constraints that these two countries had to face in the process of their financial integration. As we have argued, the above changes often led these countries to lose autonomy in their monetary policy. The outcome has been described in the literature as situations of an "impossible trinity." As we point out, the measures to maintain the three goals of exchange rate stability, capital account opening, and monetary autonomy often turn out as not only impossible, but also contrary to the interests of the real economy-e.g. depressing further the level of activity in a bid to contain inflation. The contractionary effects that result within the country are also likely to spill over to other countries by shrinking the magnitude of import demand from the former. Financial integration also instills added degrees of volatility in multiple markets: for markets of financial assets, commodities, and real estates. As we will observe in the following pages, both China and India have faced added degrees of volatility in all three of those markets since their deregulation.

We initiate the discussion by providing in section I of this paper an account of the prevailing global imbalances, dwelling on countries with large current/capital account imbalances. Countries with current/capital account surpluses per force experienced reserve accumulations in the process. A narration as above is followed by an account, as well as a critical assessment, of interpretations as are often advanced in the literature on issues relating to global current account imbalances. Section II invokes the theoretical premises of what in the literature is known as the "impossible trilemma," of continuing with free capital flows and exchange rate management along with monetary autonomy. While questioning some of the assumptions behind the static framework underlying the above theorem, which is 
essentially an offshoot of the Mundell-Fleming IS_LM framework for open economies, we draw attention to the relevance of uncertainty and expectations as dimensions that can make the analysis relatively complete. Section III dwells on China and India, providing instances of the trilemma, which include the limits faced in pursuing an autonomous monetary policy to instill growth in the face of instabilities. These instabilities are related to changing expectations in the deregulated financial sector, which include the open capital account. Section IV brings together the policy conclusions, which question the current ethos of policy making in de-regulated markets.

\section{SECTION I. GLOBAL IMBALANCES AND THE PREVAILING INTERPRETATIONS}

Concerns about the large and continuing current account deficit of the US and the unsustainable debt for countries in Southern Europe have alerted the advanced countries and their policy makers - especially with recent upheavals in the global financial markets. In the analysis of this turmoil, the large imbalances in current accounts of countries is often viewed as the major cause behind the global financial upheavals, thus ruling out other aspects that are no less important. Thus, the US' current account deficit is viewed as responsible for its contractionary effects on the largest economy in the world, with its dampening effects on the global economy. With the dollar being used in the majority of international transactions and continuing to sustain its value in terms of other currencies, the build up of the imbalance leaves it open as to whether the dollar can continue around its current exchange rate in the coming years. A sudden depreciation of the US dollar, as is obvious, is capable of initiating major disruptions in both global trade and payments.

Current account imbalances also relate to countries like Greece, Ireland, Portugal, and Italy, who all have current account deficits resulting in unsustainable levels of debt. The latter has already placed the eurozone in limbo, with short-term measures of debt rescheduling on condition of austerity — often at the initiative of rich European Union (EU) nations like Germany and France.

In the literature, China's trade surplus and US' current account deficit are often paired as major sources of global payments imbalances. As for the US' current account deficit, often US monetary authorities point to the undervalued RMB rate, which they believe to be a major factor behind the US' large trade deficit with China. A negotiation of 
the dollar-RMB rate, however, naturally remains subject to how China views it. In the same context, reserve accumulations in China and its deployment in US securities are viewed as further evidence of the lack of balance in international payments. Analysis of global imbalances also addresses the steady accumulation of reserves by the emerging economies as a whole - especially in regards to reserves held by China at $\$ 3.23$ trillion, followed by those of Russia at $\$ 516$ billion, Brazil at $\$ 349.7$ billion, and India at $\$ 311.2$ billion (September 2011). The levels above contrast the stock of reserves held by the euro area as a whole at $\$ 873$ billion, and by Japan at $\$ 1200$ billion — not to mention those of the US and the UK at respective levels of $\$ 146$ billion and $\$ 123$ billion only, all at end of September 2011 (IMF 2012).

Stocks of official reserves held by the emerging economies are usually invested in assets that are considered relatively safe. Thus, US Treasury bills have been a major item in such investments. Data released by the US Treasury indicate that China's holding of US Treasury securities at $\$ 1.16$ trillion by December 2010 was more than a quarter (26.14 percent) of the aggregate foreign holdings of US Treasury securities at $\$ 4.43$ trillion total. The remaining three countries in the BRIC group (Brazil, India, and Russia) had between them $\$ 377$ million (8.4 percent) by the same date (US Department of the Treasury 2012). Thus, China's official reserves have naturally drawn attention as a major prop in the story relating to global imbalances.

From an accounting point of view, current account surpluses and deficits represent imbalances between savings and investment at national levels. To restore balance as suggested, especially for China and other surplus countries having excess savings, deflationary policies are recommended along with revaluation of their national currency. Given the general attraction of dollar-based assets, the US is often viewed as a "passive" partner only adjusting to the "savings glut" of the East Asian countries (including China). ${ }^{1}$ As pointed out by Ben Bernanke in his oft-quoted speech of 2005, current US account deficits have been a consequence of the "savings glut" in China and other East Asian countries, and these countries have been accumulating international assets as a "cautionary step" on the basis of what they experienced during the Asian crisis of 1997-08. Apprehending problems in continuing with these current account (and savings/investment) imbalances, Bernanke suggested more investment/savings in the surplus /deficit countries,

\footnotetext{
${ }^{1}$ For a position along these lines from a think tank within US, see Dunaway (2009).
} 
which include China and the US (Bernanke 2005). Responding to a suggestion that had its origin in a recent G-20 meeting, an author from a radically different point of view argued that China should no longer lend to the "troubled" euro-area nations. ${ }^{2} \mathrm{He}$ also pointed out that by holding a large stock of US securities (which is nearly 23 percent of US bonds) as well as RMB liabilities, China has gotten trapped in the rigmaroles and the uncertainty surrounding the dollar-RMB exchange rate. It is pointed out that the US dollar has devalued by 94 percent between 1929 and 2009. If, at the moment, China acts by sharply unloading the US securities, there could be chaos in the financial market (Yongding 2010). The same author also mentions the operation of speculation in the Chinese economy, despite the recent official clampdown in the housing /real estate markets and the underground credit network (which is indicated by the recent collapse of the Wenzhou credit market). Incidentally, in recent times, real investment happens to be the major source of fixed asset investment in China. ${ }^{3}$

As mentioned in a recent study from the Bank of International Settlements, links between current account imbalances, changes in stocks of reserves, and a financial crisis can be questioned if one considers the gross inflows of capital that impact the private transactions - especially via the banking sector - that, in turn, affect the level of liquidity and credit in the receiving country (Borio and Disyalat 2011). Others have also questioned the "savings glut" argument as an explanation of the global imbalances and the crisis by pointing out that the large current account deficits incurred by the US are due more to domestic policies (Bottelier 2011). It has been suggested that as remedial measures, the US needs to rebalance its own economy by keeping consumption growth below GDP growth while strengthening international competition (Bottelier 2009).

Arguments related to the global imbalances take a different tone when an explanation is sought in the cost-competitiveness enjoyed by the surplus country (China) in terms of the advantages of cheap labor cost as well as an undervalued exchange rate. Identifying the cost advantage as "enormous arbitrage opportunities in labor rates," a study by Lowell (2010) points at the tendencies for multinational corporations (MNCs) to cluster in such places, "reflect[ing] the economic laws of gravity." However, as a remedial measure, the author

\footnotetext{
2 “China Must Avoid Lending to Troubled Euro-Asia Nations, Yu Yongding Says,” Bloomberg.com, September 13, 2011 http://www.bloomberg.com/news/2011-09-14/china-must-avoid-loans-to-troubled-nationsyongding.html

${ }^{3}$ Yu Yongding, “The Chinese Bear's Feeble Growl," Project Syndicate, November 29, 2011 http://www.project-syndicate.org/commentary/the-china-bears--feeble-growl.
} 
suggests a 30-50 percent devaluation of both the dollar and the euro in order that the exchange rates of those currencies "reflect the purchasing-power-parity (PPP) exchange rates of emerging-market countries more closely" (Lowell 2010). There have been related concerns regarding the exchange rate, holding the inflexible exchange rate policy of China and other emerging-market economies as responsible for the continuing global current account imbalances. ${ }^{4}$

Opinions on the mounting current global account imbalances, centered on the US and China, thus reflect divergent positions. While a standard position reverberates around the excess savings in China and the undervalued RMB exchange rate argument (which, incidentally, continues to be the official line of thinking in the US), interpretations advanced from other quarters provide a different picture and policy conclusions. But the focus in both has been around the possible consequences of the continuing imbalance on the global economy as a whole; which leaves out the effects at national levels, an aspect we will deal with in the following pages.

\section{SECTION II. CURRENT ACCOUNT SURPLUSES AND POLICY OPTIONS}

Attention paid to the global current account imbalances, discussed above, leaves out aspects which include the limited policy options that remain for countries with current account surpluses. The latter relates to what is described in the literature as an "impossible trilemma:" allowing capital account convertibility (CAC) along with a managed exchange rate while trying to maintain an autonomous monetary policy. Of the three variables mentioned above - which comprise the "impossibility" theorem - the option of reversing openness of the capital account by resorting to controls is more or less ruled out, especially in terms of the branch of open economy macroeconomics embedded in the above strategy. Hence, the choice of policy makers remains between management of the exchange rate (which otherwise moves freely with the market) and national autonomy in monetary policy. Again, movements in the exchange rate, if left to the market, often clash with other goalsespecially when inflows of capital push up the exchange rate of the local currency, which worsens the trade balance under a "Dutch Disease syndrome." Thus comes the need to manage the real exchange rate, say within a band, at a crawling peg, or at a fixed real rate

\footnotetext{
${ }^{4}$ Arvind Subramonian, "China Is the Key to Unwinding Global Imbalances," Financial Times, April 20, 2010 http://www.ft.com/cms/s/0/f4696136-4caa-11df-9977-00144feab49a.html\#axzz1pCDb2Yws. 
which maintains the competitiveness of domestically produced goods, which leaves out the third option - to follow an autonomous monetary policy.

What then remains as the conventionally accepted parameters of monetary policy in an open economy? Situations of excessive flows of capital to a country generate tendencies for local currency to appreciate in the foreign exchange market. The above often leads to efforts on the part of monetary authorities to sterilize the influx of foreign exchange with direct purchases of the latter in the market, which adds to official reserves. The latter, in turn, amounts to an increase in high-powered money - and the related increases in money supply — contributing to pressures on monetary authorities to adopt policies towards inflation-targeting. Consistent with the monetarist frame of analysis (as in the MundellFleming model and in its sequel, the "impossible trinity" theorem), monetary authorities put "inflation targeting" as the main agenda of their action. Little attention, however, is paid to the need to harness monetary policy in the interest of the domestic growth process, which remains as no less important to the national economy. Moreover, there is hardly any attention paid to the related effects in terms of curbs on social sector spending and public investments, which come as a consequence. With inflation targeting as the primary goal of monetary policy in an open economy that has both CAC and managed exchange rates, sale of stabilization bonds has been a convenient tool for achieving monetary stabilization. A problem as above is being faced by developing countries like China, India, and a few other emerging-market economies, with their demonstrated tendencies to accumulate official reserves in key currencies. Increases in reserves are also desired by monetary authorities in order to protect the exchange rate of their national currencies.

The notion of "impossible trilemma," as pointed out by Paul Krugman, is based on the Friedman-Mundell-Fleming IS-LM-BP framework of open economy macroeconomics with implications in line with a flexible exchange rate policy. ${ }^{5}$ However, as Palley (2009) pointed out, "The impossible trinity provides an incomplete policy menu that leaves much off the table. This omission includes a) coordinated monetary policy across countries; b) managed exchanged rates between countries; and c) managed capital flows." The "menu" above, however, leaves much to be fulfilled, especially in the context of the current global financial scenario.

\footnotetext{
${ }^{5}$ Paul Krugman, "O Canada: A Neglected Nation Gets Its Nobel," Slate Magazine, October 19, 1999 http://www.slate.com/articles/business/the_dismal_science/1999/10/o_canada.html.
} 
Further analysis of the notion of the "trilemma" offers a contextualization of it in terms of the prevailing pattern of global financial flows and imbalances. Interpreting the large reserves held by some emerging economies, it is maintained that "in the absence of a major reform of global financial architecture, emerging markets remain exposed to sudden stops and deleveraging crises" (Aizenman 2010). These economies thus had an additional urge to hold these reserves as a precautionary measure. According to this study, these countries are thus faced with what has been described as a "quadrilemma," rather than a "trilemma," which is explained by the "self-insurance" motive on the part of those countries faced with additional uncertainties in the global financial market. The study also points at financial deepening (as recorded in the rising M2/GDP ratio) as one more reason on the part of those countries to maintain higher reserves as a measure to tackle possible flights of capital by domestic residents.

A qualification, as above, while adding a new dimension concerning "uncertainty," also succeeds in revealing the conceptual weaknesses of the formulation that we hinted at earlier in this paper. Thus, the trilemma (or even the quadrilemma) essentially postulates a static framework in terms of the intersecting IS-LM-BP framework. With exchange rates, monetary policy (including interest rates), and both the magnitude and composition of capital flows all being subject to volatility that is hardly predictable, policy options faced by the concerned countries remain even more constrained - an aspect that provides an interpretation of the high reserves maintained by those countries. The latter, in turn, impacts the policy options in several ways. Thus, the prevailing pattern of international financial transactions and the global current account imbalances, while generating the "excess" reserves held by the emerging-market countries, need to be viewed in the context of the uncertainties and the related compulsions as are per force faced by these countries in the deregulated financial market.

\section{SECTION III. POLICY OPTIONS IN THE EMERGING MARKETS OF CHINA AND INDIA}

One can, with the above background, provide a better understanding of related policy issues in the high-growth countries like China and India, much of which are induced by developments in the global financial markets. Contrary to the notion of a "savings glut" suggested by Bernanke and some others, both countries have somehow been subjected to a 
path of passive adjustments, to inflows of speculative (or other) capital that originate from overseas and are thus external to their economies. The adjustments affect their options in formulating their domestic monetary policy, which includes responses to the changing money supply, changes in interest rates abroad, and other related matters.

\section{China}

China's integration into the global markets was matched by spectacular increases in its trade surpluses and net capital inflows, intercepted by some declines after the global financial crisis of 2008-09. (The trade surpluses rose from an average of $\$ 375.7$ billion during 200004 to $\$ 2.83$ trillion during 2005-10). This was combined by similar increases in foreign direct investments (from $\$ 47.79$ billion on average in $2000-05$ to $\$ 185$ billion by 2010 ) and in portfolio investments (from an average of \$6.39 billion during 2000-05 to an annual average of $\$ 25.91$ billion by $2005-10$ ). Those led to expansions in the stock of official reserves (excluding gold) held by the country, which has risen sharply from an average of $\$ 339.5$ billion during 2000-04 to an average of \$1.77 trillion during 2005-10. ${ }^{6}$ According to unofficial estimates, the recent value of China's official reserves exceeded $\$ 3$ trillion by March 2011, reaching \$3.27 trillion and \$3.18 trillion, respectively, by October and December of $2011 .^{7}$ The steady deregulation of China's financial market which started in 2005 has been continuing without much interruption. Rising capital inflows, however, did not impact the managed exchange rate of the Yuan, which remained steady at 8.28 RMB per US dollar between 2000 and 2004. Responding to pressures to adjust the currency upwards, especially by the US, the RMB was de-linked from the US dollar by an official announcement in July 2005. This led to a moderate revaluation of the currency to 8.11 RMB per dollar. Chinese currency has been appreciating moderately since then, with the most recent figure quoted in the market at 6.38 RMB to a dollar on September 2011. ${ }^{8}$ However, the official Chinese stance (of continuing with monetary interventions in a bid to avoid major appreciations in the national currency) seems to have prevailed even with moderate

\footnotetext{
${ }^{6}$ Unless otherwise mentioned, data presented in this section are all from IMF, "International Financial Statistics," http://elibrary-data.imf.org/FindDataReports.aspx?d=33061\&e=169393

7 “China's foreign exchange reserves, 1977-2011," Chinability.com http://www.chinability.com/Reserves.htm

${ }^{8}$ XE Corporation, "X-Rates: Chinese Yuan,”X-Rates http://www.X-rates.com/d/CNY/table.html
} 
appreciations, especially in view of a simultaneous depreciation in dollar, a major link currency in currency markets.

China has been experiencing twin surpluses between its current and the capital account. This has contributed to the accumulation of official reserves, which at around $\$ 3.18$ trillion, is unprecedented by any previous record. We analyze below the related domestic impact in the domestic economy, which, as pointed out above, not by posing a "trilemma" (or "quadrilemma"), can also be operative in limiting options to official policies.

To reiterate what we have already mentioned earlier as the trilemma under open capital account, entry of capital from overseas tends to have its initial impact on the nominal exchange rate of the domestic currency. To avoid an appreciation of the domestic currency, monetary authorities often resort to direct purchases of foreign currency, which simultaneously generates high-powered money (reserves) with proportionate additions to domestic money stock. Thus, reserves, as high-powered money, provide sources to additional supply of money, an aspect which adds to the pressures on monetary authorities to tighten money supply. To avoid further additions to liquidity in the market, the monetary authorities often tend to sterilize a part of the additions to money supply through sales of official bonds (open market operations). Additionally, the monetary authorities also tighten credit by using other tools (like cash-reserve ratios, statutory liquidity ratios, hikes in repo, reverse repo rates, and prime lending rates) in a bid to control the inflationary tendencies that may result from monetary expansion. Policies such as these, prompted by financial flows from abroad, not only deprive the receiving countries of their autonomy in the choice of their economic policies, but can also interfere with goals to achieve growth and expansion for their real economy, especially with contractionary effects on supply of credit.

As for China, the continuing trade surpluses and the rising capital inflows (especially foreign direct investments) that have continued along with a managed exchange rate policy have led to steady increases in officially held reserves. One observes continuous monetary expansions, especially over the last decade (see Appendix: Chart B). The monetary authorities injected liquidity further after 2008 by using fiscal expansionary policies, a reversal of open market policies (by stopping sales of bonds), and with adjustments in the cash reserve ratios maintained by banks (see Appendix: Chart A). The measures led to liquidity expansions in the market and a lowering of interbank lending rates, which fell even below deposit rates. The trend continued and M2 went up successively during the following 
years. As held by some, the changes signified a monetary policy which was "too loose," and that "in accumulating the large stock of US Treasury bills, China 'faces a triple whammy' by facing possible capital losses with a possible drop in dollar exchange rates and in prices of the T Bills, plus an inflationary pressure in the domestic economy" (Yongding 2009).

Views held by scholars differ as to whether China has retained autonomy in her monetary policy in the face of the obstacles underlying the trilemma and its impossibility. According to a study by Reade and Volz (2010), the test should not rely only on whether short-term interest rates in China are driven by the Fed's monetary policy (i.e., US interest rates). The authors argue that by employing capital controls and by relying on measures other than interest rates, China has been able to maintain "relative autonomy" in monetary policy. Thus, the use of policy devices "other than interest rates" (like reserve ratios, open market operations, etc.), in essence, is also part of the package of monetary policy followed by China. From this angle, interest rates have not always been the primary instrument of policy in the country (Reade and Volz 2010). Incidentally, the logic applies to countries like India, as well, as we indicate later in this paper.

As for related studies in the literature, we can also refer to another study by Patnaik and Shah (2010) on the "impossible trinity" question as it relates to Asian economies. While we do not share the prescriptions offered by the authors to use flexible exchange rates as a way around the impasse in the trilemma, we agree with what the authors view as similar situations of a trinity in high-growth Asian economies like China and India. Using measures of capital account openness by means of the Chinn-Ito database and also the gauge of financial opening (or integration) by using Lane-Milessi-Ferretti calculations (which rely on ratios of stocks of financial assets plus liabilities to cumulative flows of GDP), the study arrives at a measure of de jure capital account opening for China and India during recent years. Indicators as above, matched with exchange rates that are rather inflexible, have led these two countries, as pointed out in the paper, to situations of an "impossible trinity." Monetary policy (or management), as we have emphasized earlier, consists of a package that includes the different tools that can be used to influence the level of liquidity. Thus, use of interest rates is but one of many devices that include cash-reserve ratios for banks and sale of bonds (open market operations). It is possible to observe that Chinese monetary authorities have been consistently making use of all three above in a bid to contain the changing level of liquidity as well as the movements in the price index. 
Changes in China's external accounts with the large trade surpluses and net inflows of FDI, and (of late) portfolio capital, have caused phenomenal increases in the country's official reserves. As a consequence, the domestic economy witnessed steady expansions in liquidity. Attempts to neutralize the upward pressures on RMB rates and the price rise in the domestic economy included direct purchases of foreign currency as well as sales of marketable bonds by the monetary authorities. The changing scenario between 2002 and 2010 can be observed in Chart A in the Appendix. ${ }^{9}$ More recently, by the second quarter of 2011, prices rose further by 5.4 percent (yoy) (PBoC 2011a). The reserve ratio actually increased seven times over the first three quarters of 2011, with the ratio rising as much as by 21.5 percent by October 21, 2011 (Ehnts and Körner 2011).

Measures on the part of monetary authorities to control the recent inflation also included sales of official bonds, which depressed the domestic interbank lending rate by 0.41 percent (yoy) in December 2011, and it reached a low of 3.74 percent (PBoC 2011a). It can be expected that such actions led liquidity in the market to subside, especially as a consequence of the aggressive sales/purchases of bonds in response to changes in cash flows and the related changes in prices.

To arrive at a conclusive argument, we have used the monthly as well as annual data for China for 2006-2010 for a few variables. Those include: official reserves, M2, RMB exchange rates vis-à-vis the US dollar, changes in the price levels (CPI), sale of government bonds, bank rates and lending rates, and, finally, China's trade balance. The data has been used to test the correlation among them.

Considering first the correlation results at 1 percent level of significance, we observe the following:

1. Changes in reserves and those in money supply are positively correlated, as is expected when policy changes in interest rate are guided by changes in money supply. The result holds for both monthly and annual data for 2006-2010 (see Appendix: Tables 3 and 4).

\footnotetext{
${ }^{9}$ The pattern tallies with the data released by the People's Bank of China (PBoC), which indicates $a$ drop in the consumer price index (CPI) between the first and third quarters of 2009 by 1.1 percent (on yoy basis) and a drop in CPI at (-)1.3 percent during the third quarter, itself, of 2009. Loans offered in domestic currency during the quarter expanded by 34 percent (yoy) while cuts were announced in reserve ratios, and sale of bonds were fewer (or none) — all in an effort to revamp the economy from its post-crisis slump (PBoC 2009).
} 
2. Money supply and bond sales are positively correlated, as is indicated by annual data for 1998-2010 (Table 1). Again, this is expected, and shows use of monetary policy to ward off expansions in liquidity.

3. Reserves and exchange rate of RMB, however, has a negative relation during 2006 and 2010 (Table 3). This can be interpreted by the management of the exchange rate in China, which continued even after the delink with the dollar in 2005.

Looking at the results at 5 percent significance level, the following can be reported:

1. Sale of bonds and movements in prices (CPI) bear a positive relation between 1996 and 2010 (Table1). This also shows a perceptible effort on the part of monetary authorities to control prices by sales of bonds.

2. Money supply (M2) and reserves are positively correlated on the basis of annual data 1998-99-2010 (Table 2), a result that is also confirmed at 1 percent level for the same period (Table 3), as reported above. The link confirms the impact of trade surpluses and net capital flows on money supply via changes in official reserves.

3. Lending rates and bank rates also move together, which is expected (Table 1).

Results as above indicate a distinct impact of China's external sector transactions on the package of monetary policies relating to the domestic economy. Accumulation of reserves, which resulted from the trade and capital account surpluses the country enjoyed, impacted the supply of money, which in turn prompted the use of sterilization policies via sale of bonds, and also via hikes in reserve ratios, especially during 2010 when the latter was adjusted upwards three times (Yongding 2011). Incidentally, as pointed out, a large part of the RMB 9.7 trillion post-crisis stimulus during 2008 and 2009 was channeled via the banking system, which was responsible for additional bank credit amounting to RMB 7.3 trillion during the first half of 2009. Since such expansions were made possible under government pressure, it did not have to rely on monetary base (including reserves). One also observes that the People's Bank of China (PboC) stopped selling central government bills in the fourth quarter of 2008, which coincided with the onset of the global recession. Steps as above led to spectacular expansions in liquidity in the market, pushing down the interest rate in the interbank market lower than the deposit rates.

The policy moved in reverse by 2010, as inflation paired with monetary tightening set the bank credit quota at RMB 7.5 trillion (compared to RMB 9.7 trillion in 2009). Also, as mentioned earlier, reserve requirements of banks were raised three times during the year, 
open market operations were used more effectively, and interbank interest rates were increased (Yongding 2009). One can notice the sharp swings in interest rates, with the lending rate ranging between 5.3 percent to 12.6 percent, and the bank rate between 2.7 percent to 10.7 percent between 1990 and 2010 (see Appendix: Charts A and C). One can even relate such swings in interest rates to the changing global financial scene during the Asian crisis, inducing steep cuts in China's interest rates between 1997 and 1999, to be followed by upward movements from 2005 along with the peaking of capital inflows, and once again, with cuts in the country's interest rates to combat the contractionary forces during the recent global downturn of 2007-08. The latter was followed by a renewed tightening of rates over the period of 2009-10. Since 2005, the steady pace of liberal capital flows has led to both expansions in portfolio inflows and stock market capitalization. ${ }^{10}$ Evidence as above help us to conclude that both free flows and the volatility of overseas capital had a significant impact on China's monetary and related policies - curbing, in the process, monetary autonomy in the economy.

\section{India}

With near full convertibility of the Indian rupee and near free flows of capital, official reserves held by India have been rising steadily, peaking by August 2011 at a level of $\$ 321$ billion - which, after China, is one of the highest held by the emerging-market economies. We draw attention in the following pages to the related changes within the economy, and especially to the limited options that policy makers have been faced with. Successive liberalization of global capital flows to India since 1992-93 led to a steep rise in the inflows of foreign direct investment (FDI) and especially of portfolio capital to the country, with capital account surpluses much in excess of the current account deficit the country was experiencing. However, official interventions in the forex market successfully transferred a considerable part of the currency inflows to the exchequer, thus contributing to expansions in the level of official reserves - while avoiding appreciations of the rupee rate. As already pointed out, additions to reserves (high-powered money) are capable of contributing monetary expansions, in turn posing additional problems for policy makers.

We have observed in an earlier paper that monetary policy in India has often been conditioned by the exigencies related to the external sector, and in particular, to the direct

\footnotetext{
${ }^{10}$ See Sen (2007).
} 
and indirect repercussions of the surges in capital flows. ${ }^{11}$ Faced with expansions in money supply, which nearly tripled from around Rs 2005 thousand crores in 2003-04 to nearly Rs 5600 thousand crores by 2010-11, and with inflationary pressures especially on food items, authorities have been attempting monetary sterilization by selling government bonds and raising the cash reserve ratio (CRR), among other things. Incidentally, sales of government bonds were also in conformity with the marketized borrowing program of the government, which, in terms of the statutory norms of the Fiscal Responsibility and Budget Management Act of 2003 (FRBMA), replaced the nonmarket borrowings of the government from the central bank (earlier practiced as deficit finance). Market borrowings also helped in controlling the fiscal deficit as a proportion of the GDP, as needed in terms of the statutory requirements.

Attempts were also made by monetary authorities to tighten/cheapen credit with hikes/reductions in interest rates, changes in repo as well as reverse repo rates, and variations in CRR maintained by banks with the Reserve Bank of India (RBI) (Sen 2010). To verify the arguments, we have used the data relating to $\mathrm{M}_{3}$, exchange rate of rupee (ER), market borrowings of central and state governments (MBCS), FDI, portfolio flows, reserves, gross fiscal deficit (GFD), gross primary deficit (GPD), and some items in the budget under heads of expenditures for the period between 1990-91 and 2010-11.

Results are provided in Tables 4 and 5 of the Appendix showing the correlation coefficients between variables for annual values relating to the above years. These indicate positive correlations at 1 percent level of significance among levels and log values for the majority of variables. The logic, as explained earlier in the context of China, relates to a sequence that includes the rising capital inflows (FDI and portfolio), rise in reserves and related expansions in money supply that were sought to be neutralized with bond sales (and as can be observed from Table 6, by rise in interest rates). The pattern clearly is indicative of limited autonomy in India's monetary policy during the phase of capital account liberalization over the last two decades. (The rising budget deficits, both fiscal and primary, do not add much to the above argument but unfold some other aspects that we will indicate later).

\footnotetext{
${ }^{11}$ See Sen (2010).
} 
We also tried to test the causal links between changes in some variables by using regression results with significance at 5 percent level, while using quarterly data between 2000 and 2010 (Table 6). The results explain changes in interest rates as a positive function of growth in $\mathrm{M}_{3}$ and also inflation rate as a positive function of changes in GDP. Evidently, interest rates set by the monetary authorities during this period were in response to the supply of money, while, as mentioned earlier, the latter was subject to changes in the external sector transactions. However, the results indicate a negative causality between the same variables as we regress the data set for a longer period between 1991 and 2010 (Table 7A). The explanation rests on the standard inverse links between the interest rate and money supply in a market-determined system, with a rise in money supply existing with dampened interest rates. In contrast, the earlier case is one where monetary policy takes the lead to fix the interest in response to changes in money supply itself, as has happened since 2000 in India.

A pattern as that above clearly indicates a loss of monetary autonomy on the part of policy makers and moves that may be contrary to the interests of the real economy. As an example, one can mention the recent tightening of credit by RBI, the central bank. The above has introduced successive rounds of upward movements in interest rates along with hikes in both cash reserve ratios and open market sales of government bonds - all in a bid to mop up liquidity in the market. Thus the repo rate (which is the rate at which money is injected into the system by the central bank) was adjusted five times between May and October of 2011, rising from 7.25 percent in May to 8.5 percent in October (Reserve Bank of India 2010). Hikes such as those above were in opposition to the interests of the real economy, as is demonstrated by the noticeable drop in GDP from an average of 8.4 percent from 2009-2011 to 6.1 percent during the quarter ending in December 2011 (Reserve Bank of India 2010).

The government's monetary policy package in response to the related changes in the external sector included, as mentioned above, open market policy using government bonds. (Bonds that were sold at a value of Rs 99314 crores in 2000-01 rose to a value of Rs 111276 crores in 2010-11.) These measures of market borrowings were obviously connected to the overall limit on the fiscal deficit in terms of the FRBMA. Moreover, that such sales were prompted by rising $\mathrm{M}_{3}$ can also be observed in our tests (for data relating to the first quarter of 2000 and the fourth quarter of 2010), where sale of bonds is regressed on changes in $\mathrm{M}_{3}$ as well as inflation rate. 
Finally, as can be observed, growth rates in $\mathrm{M}_{3}$ do not bear any significant relation to price changes (Table 6), thus disputing the quantity-theoretic argument in strategies of inflation targeting. Prices, as can be argued, are also influenced by factors other than sheer money supply (e.g., supply of output).

On the whole, our exercise with data confirms the argument proposed in earlier sections of the paper that monetary policy in India has been subject to the exigencies arising out of the open capital account and the need to both manage the real exchange rate of the rupee at a competitive level and control inflation.

We now analyze some additional implications of the monetary policy package, and in particular, the effect of monetary sterilization by means of bond sales. The latter, sold to the public, necessitates the payment of interests in the budget. This adds to expenditure in the fiscal budget, which, again, is subject to the restraints of the FRBMA which limits the size of the deficit. We find that as a consequence of the rising interest bill, the deficit in the primary budget (which is fiscal deficit less interest payments), measured as a proportion of GDP, is further reduced (Table 7). With head of expenditures in the primary budget including subsidies, capital expenditures, and defense expenditures, a major brunt of the cut in the primary deficit has fallen on subsidies, which have shown a decline both as shares of GDP and as shares of government expenditure in recent years (Charts G, H, I).

The patterns indicate the following:

1. The relative drop in primary deficit as compared to the fiscal deficit, largely with steep increases in interest payments on government bonds that were sold to the public over the last few years.

2. The rising levels of market borrowings in recent years.

3. The changing composition of expenditure in the primary budget, ${ }^{12}$ with the rising level of interest payments in fiscal budget far exceeding the payments under heads of subsidies and capital expenditures, the latter being entered into the primary budget. An outcome as above as described in this section on India signifies a trade-off between achieving what is considered "financial stability" (inflation targeting, exchange rate management) on one hand, and the developmental goals of a country which include the

\footnotetext{
${ }^{12}$ In terms budget classification in India, Fiscal Deficit $=$ Total Expenditure - Total Receipts $=[$ Revenue Expenditure + Capital Expenditure $]-$ Total Receipts or, Fiscal Deficit $=[$ Interest Payments + Subsidies + Defense Expenditure + Capital Expenditure $]-$ Total Receipts. Primary Deficit $=$ Fiscal Deficit - Interest Payments $=[$ Subsidies + Defense Expenditure + Capital Expenditure $]-$ Total Receipts.
} 
pitching of a growth-inducing interest rate and commensurate levels of social sector spending on the other. The dominance of finance in policy making for the developing economies is clearly visible in these measures, following the dictates of global finance with compulsions that make for a selection of policies that are not necessarily conducive to the interests of their real economy.

The trilemma (or quadrilemma) that India has been facing with the closer integration into global financial markets has thus not only constrained its monetary policies (which have been consistently side-tracking the interests of real growth), but has also changed the composition of public expenditure - away from distributional justice to the rentier interests. Examples are not difficult to find, with RBI's use of inflationary targeting in recent times (which includes tightening of credit and successive rounds of hikes in primary lending rates and reserve ratios), despite the low growth performance of the economy, especially in the industrial sector.

\section{CONCLUDING NOTES}

Both the narrative and an analysis of the global imbalances that exist in the literature remain incomplete unless they capture the part of the story that relates to the experiences of the emerging economies that are experiencing the surges in capital flows. In addition to disregarding the implications of the capital flows on their domestic economies (especially in terms of the "impossibility" of following a monetary policy that suits growth in the domestic economy), such analysis fails to recognize that both uncertainty and changes in expectations are factors behind the build-up of large official reserves - often as a precautionary measure. The consequences, as discussed above, are more than one, affecting the fabric of growth and distribution in these economies. Incidentally, it is the flow of gross capital (rather than the net current account imbalances) that plays an instrumental role in the concerned economies by influencing the banking system, which is an argument which applies to the advanced countries as well.

Experiences of both China and India, with their deregulated financial sectors in recent years, bear testimony to the points mentioned above. While China had the capacity to make use of the fiscal budget to amend the unwanted consequences, the country has already experienced the plunge that comes with free capital flows, with volatile and short-term capital setting the direction of investments to spheres of short-term profitability. As well, the 
high level of reserves (with a large portion invested in the US) defines the significance of the US for China - not only as a major trade destination, but also as a means of protecting the value of wealth invested in the US dollar.

As for India, the country lacks the flexibility enjoyed by China in managing finance by using fiscal resources, given the norms of fiscal compression. The related effects include the volatility in the money and capital market and the related measures by monetary authorities - both in injecting liquidity as needed and, more often, in restraining the latter by using standard tools like reserve ratios, bank rates, and open market operations in the security market. The latter has already increased the budgetary liabilities under the head of interest payments, which makes it difficult to meet liabilities on other heads, like social sector spending.

Financial integration and free capital mobility, which are supposed to generate growth with stability in terms of the "efficient market" hypothesis, have not only failed to achieve their promises (especially in the advanced economies), but have pushed the highgrowth developing economies of China and India to a state of compliance - in which domestic goals of stability and development are sacrificed to attain the globally sanctioned norms of free capital flows. 


\section{REFERENCES}

Aizenman, Joshua. 2010. "The Impossible Trinity (aka The Policy Trilemma).” Working Paper No. 666. Santa Cruz, CA: University of California-Santa Cruz.

Bernanke, Ben. 2005. "The Global Saving Glut and the U.S. Current Account Deficit." Speech given at the Sandridge Lecture, Virginia Association of Economists, Richmond, VA, March 10, 2005. http://www.federalreserve.gov/boarddocs/speeches/2005/200503102/.

Borio, Claudio and Piti Disyalat. 2011. "Global Imbalances and Financial Crisis: Link or No Link?” BIS Working Paper No. 346. Basel, Switzerland: Bank for International Settlements.

Bottelier, Pieter. 2009. "China and the Financial Crisis." In Ashley J. Tellis, Andrew Marble, and Travis Tanner, Eds. Strategic Asia 2009-10: Economic Meltdown and Geopolitical Stability. Seattle, WA: The National Bureau of Asian Research.

- 2011. "Emerging Market Economies, Global Trade Imbalances, and the U.S. Dollar: An Interview with Pieter Bottelier." By Graham Webster. The National Bureau of Asian Research. http://www.nbr.org/research/activity.aspx?id=135.

Bryan, Lowell. 2010. “Globalization’s Critical Imbalances.” McKinsey Quarterly 3: 57-68.

Dunaway, Stephen. 2009. "Global Imbalances and the Financial Crisis." Council Special Report No. 44. New York, NY: Council on Foreign Relations.

Ehnts, Dirk and Finn Marten Körner. 2011. "The True Costs of Sterilization: What It Takes China to Manage Its Exchange Rate." Paper presented at the TELIS-Seminar on "Risk and Regulation," December 14, 2011. Oldenburg, Germany: Universität Oldenburg.

Government of India. 2010. Union Budget \& Economic Survey, 2009-2010. http://indiabudget.nic.in/ub2009-10/ubmain.htm.

. 2011. Economic Survey, 2010-2011. http://indiabudget.nic.in/budget20112012/survey.asp.

IMF. 2011. International Financial Statistics, China. Accessed on April 25, 2012. http://elibrary-data.imf.org/.

_. 2012. Principal Global Indicators. IMF. Accessed on March 14, 2012. http://www.principalglobalindicators.org/default.aspx.

Palley, Thomas. 2009. "Rethinking the Economics of Capital Mobility and Capital Controls." Working Paper No. 193. Amherst, MA: The Political Economy Research Institute, University of Massachusetts at Amherst. 
Patnaik, Ila and Ajay Shah. 2010. "Asia Confronts the Impossible Trinity." Working Paper

No. 10/64. New Delhi, India: National Institute of Public Finance and Policy.

People's Bank of China. 2009. China Monetary Policy Report: Quarter Three, 2009. Monetary Policy Analysis Group of the People's Bank of China. Beijing, China.

_. 2011a. China Monetary Policy Report: Quarter Three, 2011. Monetary Policy Analysis Group of the People's Bank of China. Beijing, China.

. 2011b. Balance Sheet of Monetary Authority. http://www.pbc.gov.cn/publish/html/2010s04.htm

Reade, J. James and Ulrich Volz. 2010. Chinese Monetary Policy and the Dollar Peg. Discussion Paper 2010/35. Berlin, Germany: Free University Berlin, School of Business \& Economics.

Reserve Bank of India. 2010. December Bulletin. http://www.rbi.org.in/scripts/BS_ViewBulletin.aspx.

Sen, Sunanda. 2007. "China in the Bull Shop: Dealing with Finance after WTO.” In Capture and Exclude: Developing Economies and the Poor in Global Finance. Amiya Kumar Bagchi and Gary A. Dymski, Eds. New Delhi, India: Tulika Books.

— 2010. "Managing Finance in Emerging Economies." Working Paper No. 630. Annandale-on-Hudson, NY: The Levy Economics Institute of Bard College.

US Department of the Treasury. 2012. "Major Foreign Holders of Treasury Securities." US Department of the Treasury. Accessed on March 14, 2012.

http://www.treasury.gov/resource-center/data-chart-center/tic/Documents/mfh.txt.

Yongding, Yu. 2009. "China's Policy Response to the Global Financial Crisis." Remarks prepared for the Productivity Commission's Richard Snapel Lecture. Australian National University, Canberra, Australia. November 27.

. 2010. Witness to Financial Imbalances: A Double Surplus, the Yuan Exchange Rate and the Dollar Trap. International Economic Review 3

. 2011. "China's Macro-economic Situation and some Policy Issues.” Mimeo. Paris. June 22. 


\section{APPENDIX}

\section{Charts}

Chart A China

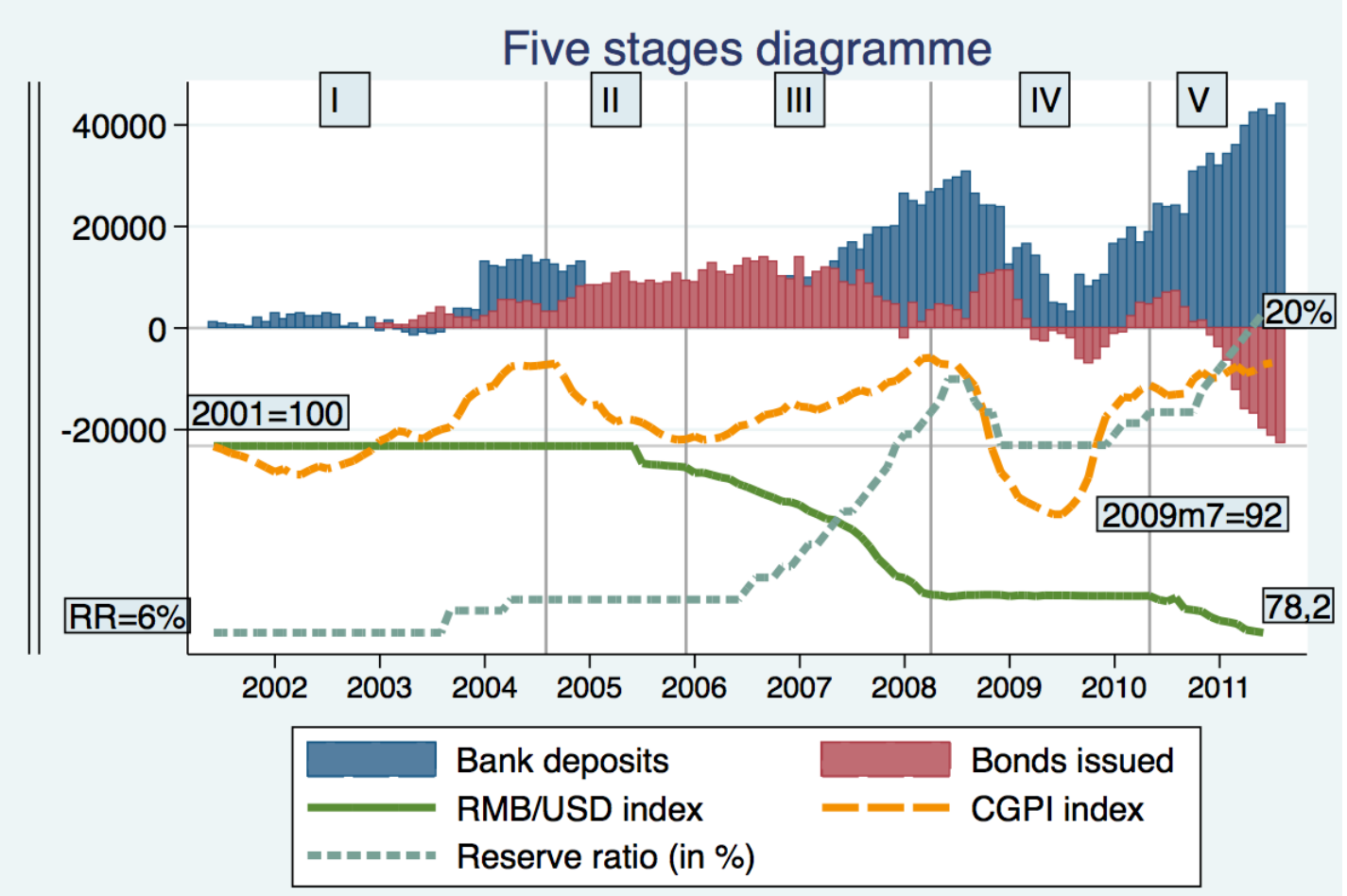

I.h.s. year-on-year changes in stocks in RMB 100m Yuan; source: People's Bank of China

Source: Ehnts and Körner (2011)

Chart B China: Changes in $\mathrm{M}_{3}, 2000-2010$

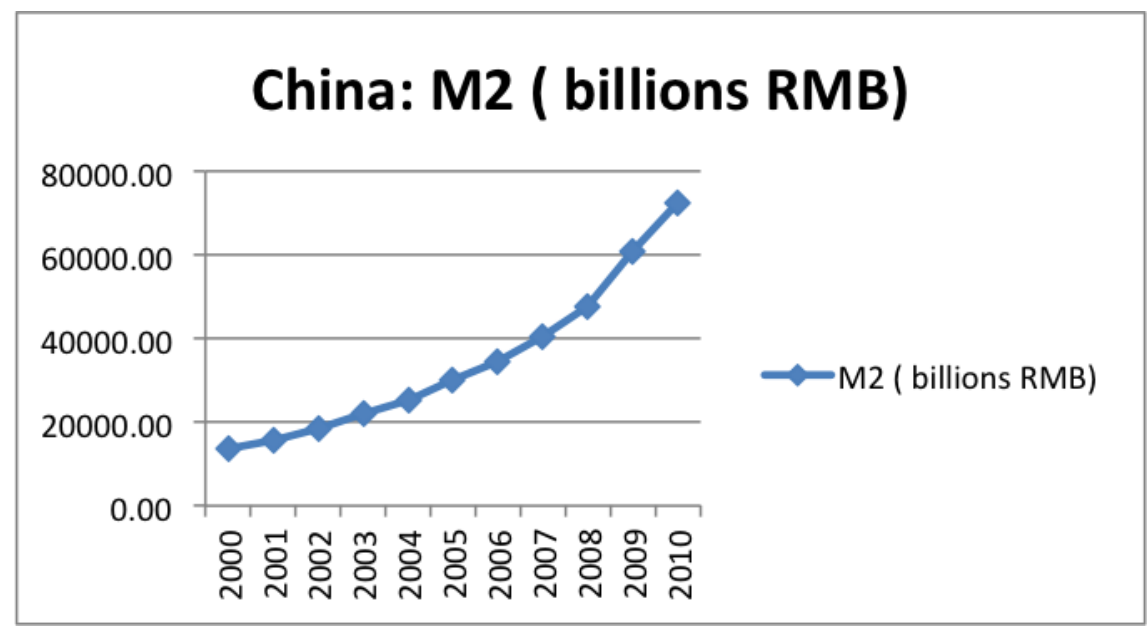

Source: IMF 2011 
Chart C China

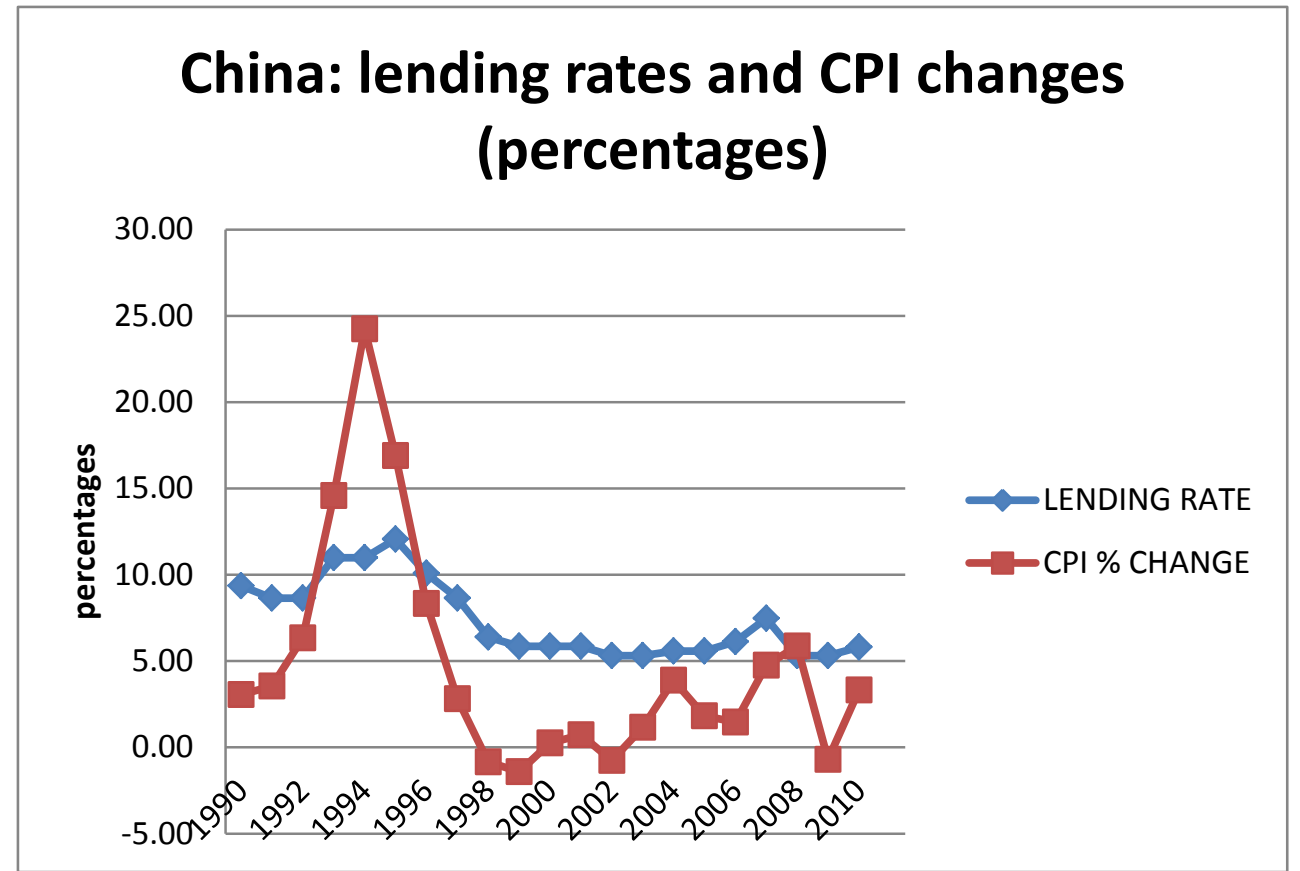

Source: IMF 2011

Chart D India: M2 and Foreign Exchange Reserves (log values)

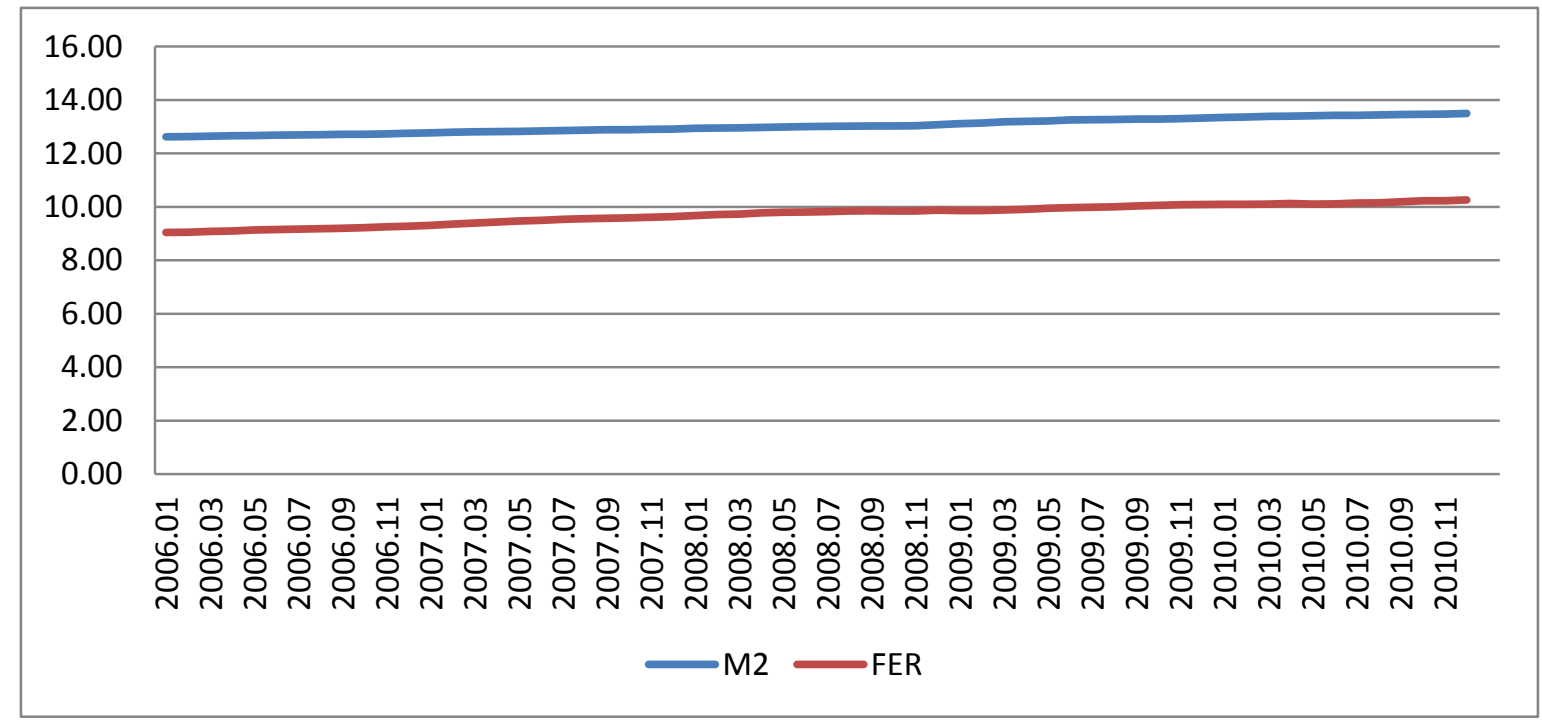

Source: Government of India 2011 
Chart E India: Fiscal Deficit, Primary Deficit, and Market Borrowings (in Rs crore)

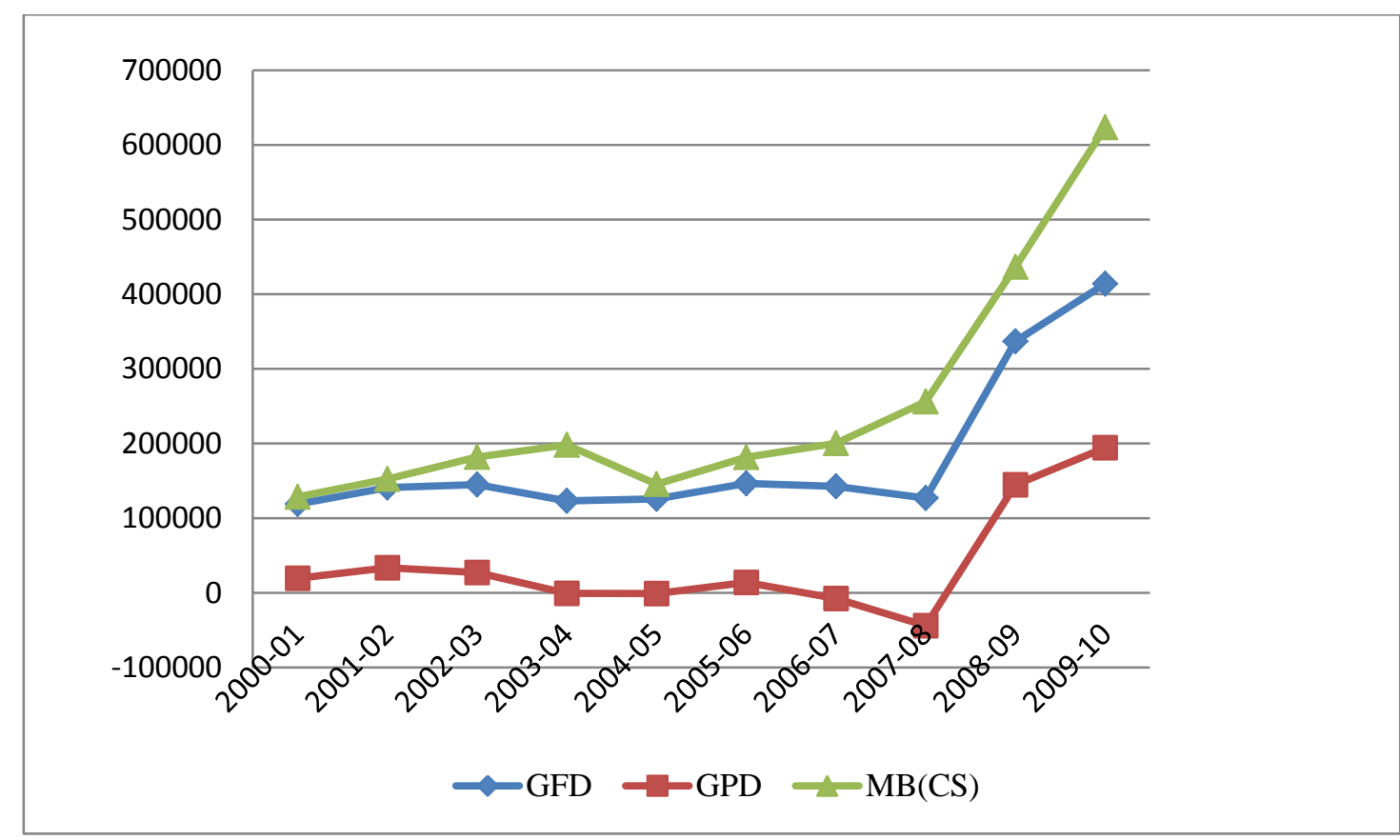

Note: GFD=Gross fiscal Deficit; GPD=Gross Primary Deficit; and MBCS=Market Borrowing of Central and State Governments

Source: Government of India 2011

Chart F India

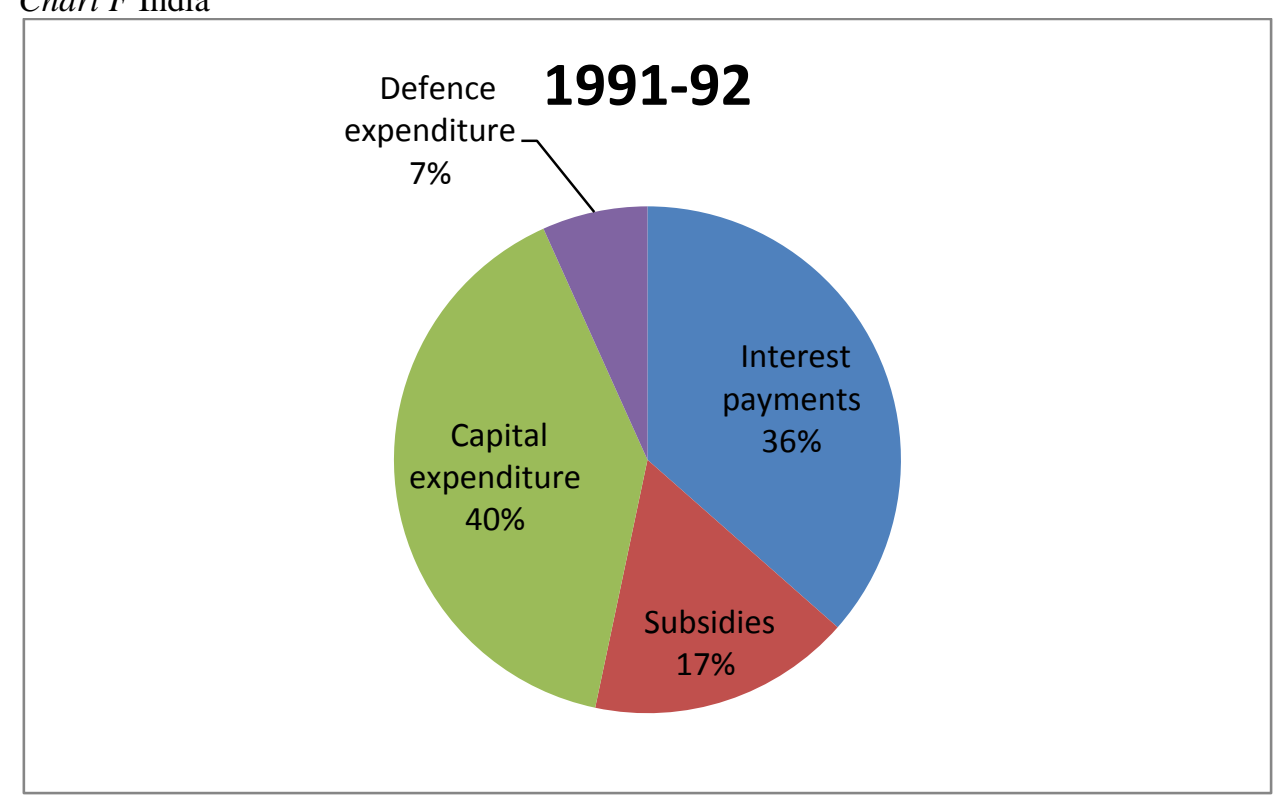

Source: Government of India 2011 
Chart $G$ India

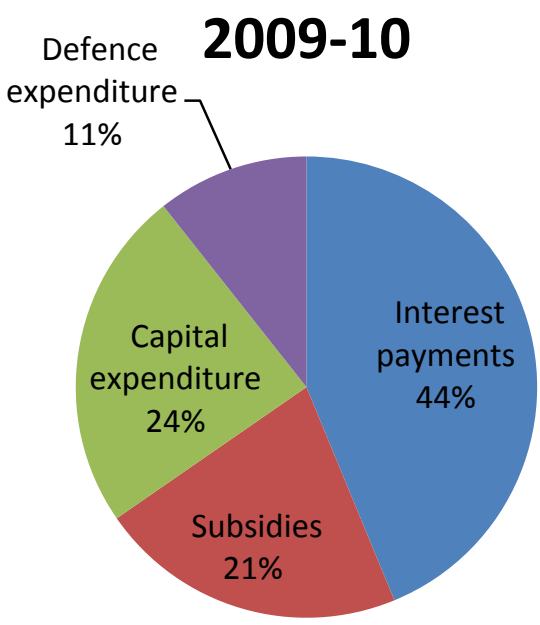

Source: Government of India 2011

Chart G(1) India: Major Heads of Expenditure: Central Government (in Rs crore)

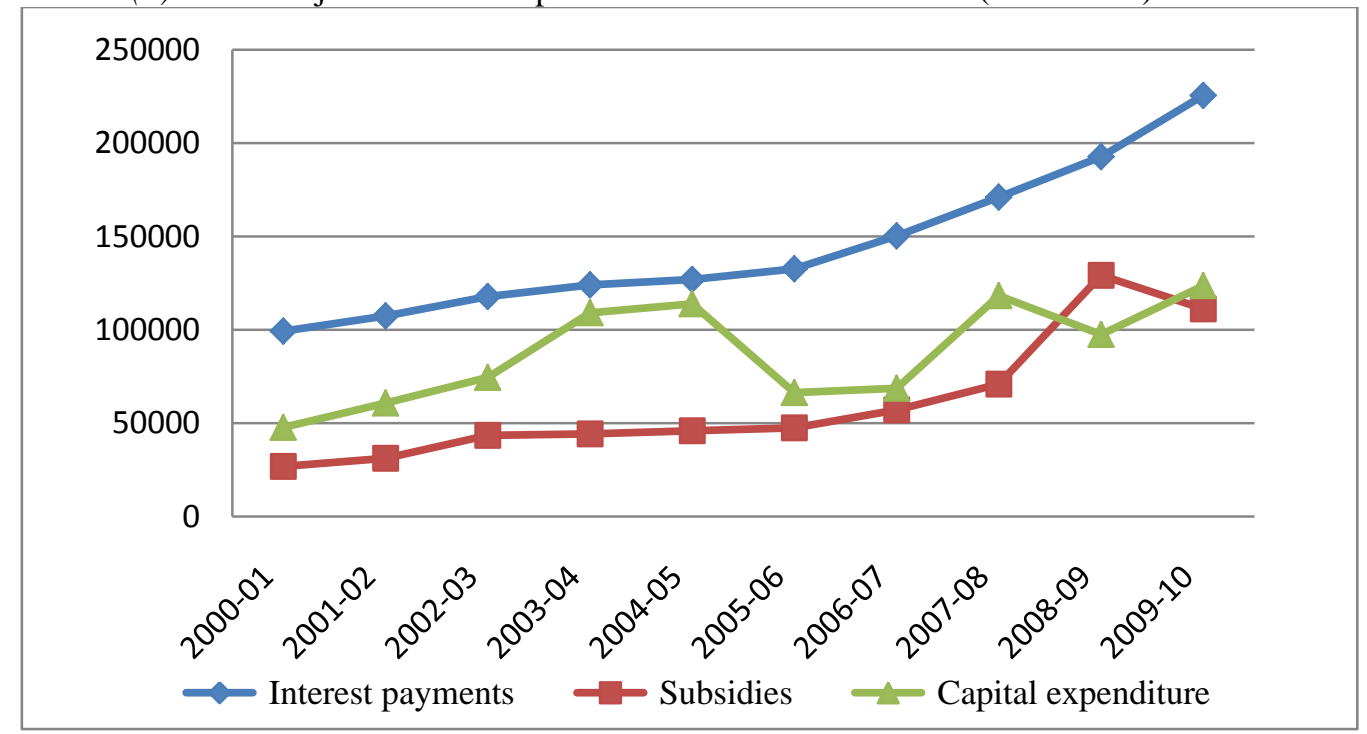

Source: Government of India 2011 
Chart H India: Subsidies as proportion of GDP

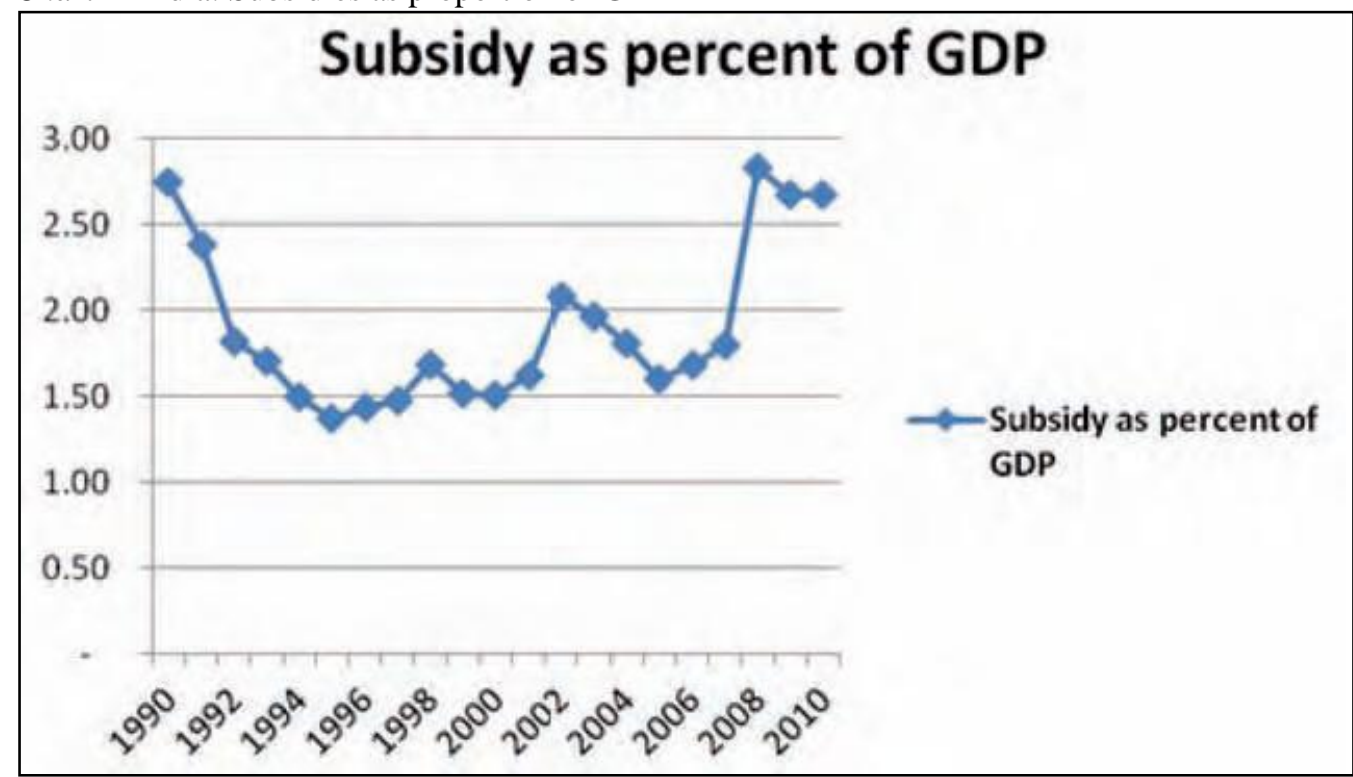

Source: Government of India 2011

Chart I India Subsidy as percent of Government Expenditure

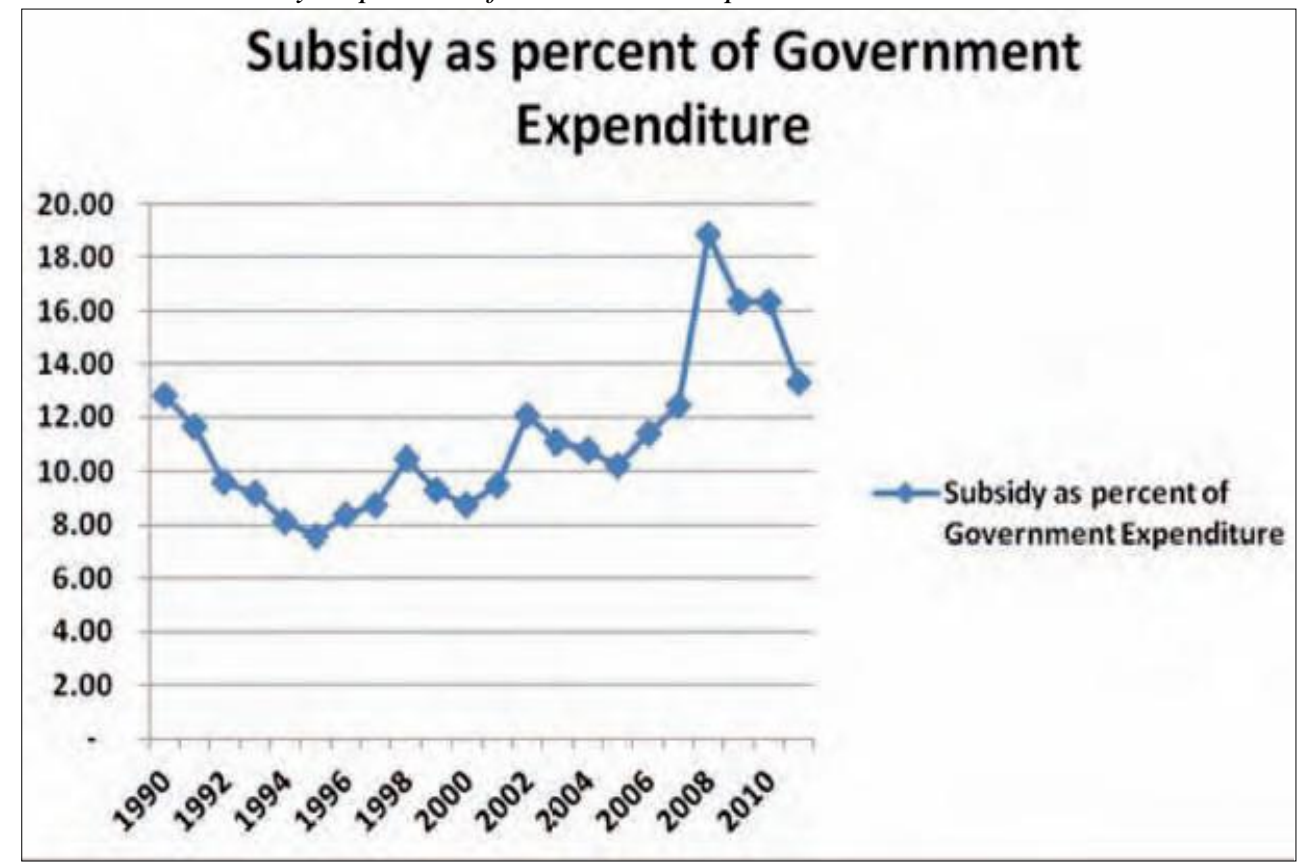

Source: Government of India 2011 
Chart J India: Stock Market Capitalization and Change in Official Reserves (in percent)

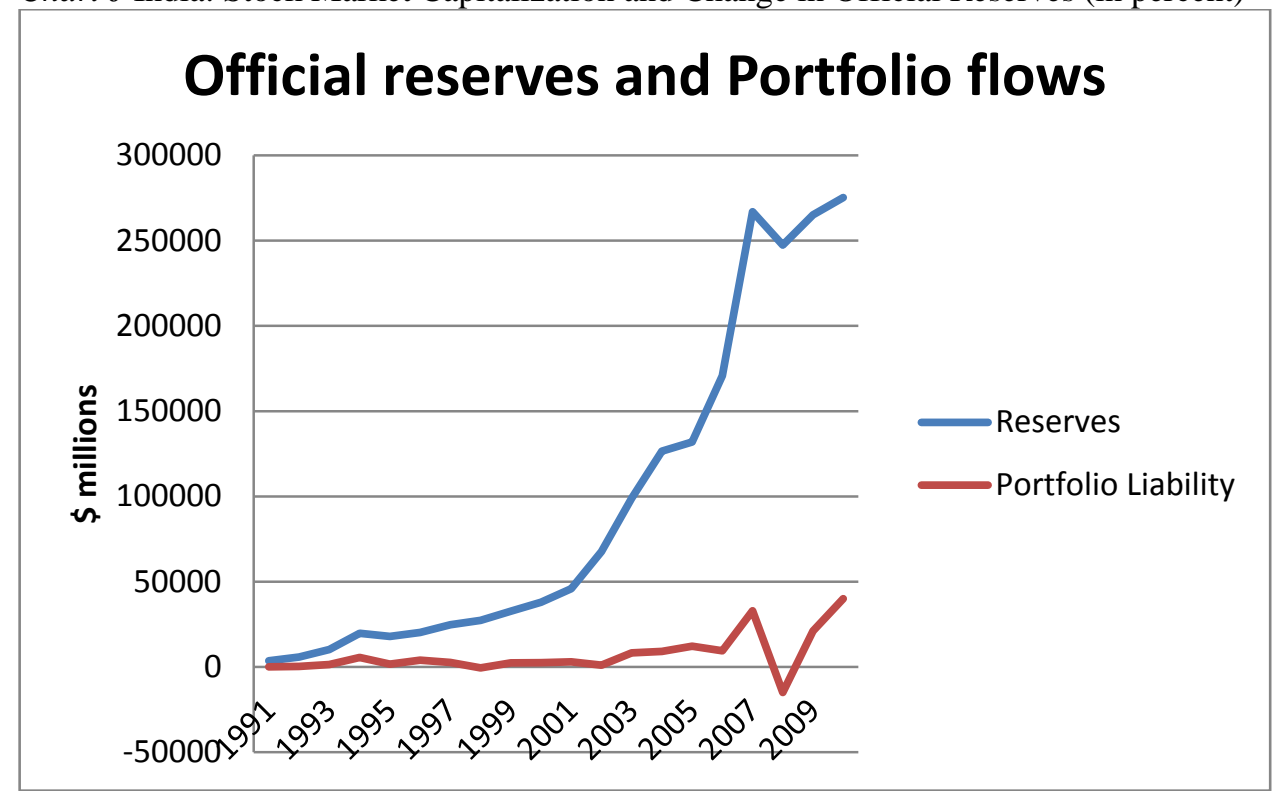

Source: Government of India 2011

\section{Tables}

Table 1 Correlation Results for China: Annual Data from 2006-07 to 2010-11

\begin{tabular}{lll}
\hline Variables & Reserves & Exchange Rate \\
\hline Reserves & 1 & \\
Exchange Rate & $(-) 0.9 * * *$ & 1 \\
Money supply & $0.98^{* *}$ & $(-) 0.8$ \\
\hline
\end{tabular}

Note: $* * *$, and $* * *$ indicate statistical significance at 1,5 and 10 percent level.

The monthly figures are converted to annual, and money supply is one year lag.

Source: PBoC 2011b

Table 2 Correlation Results for China: Annual Data from 1998-99 to 2010-11

\begin{tabular}{llllll}
\hline Variables & $\begin{array}{l}\text { Bank } \\
\text { rate }\end{array}$ & lending rate & CPI\% Change & M2 & Bonds \\
\hline Bank rate & 1 & & & & \\
Lending Rate & $0.55^{* *}$ & 1 & & & \\
CPI\% Change & $(-) 0.16$ & 0.2 & 1 & 1 & \\
M2 & $(-) 0.32$ & $(-) 0.06$ & $0.5^{* * *}$ & $0.98^{*}$ & 1 \\
Bonds & $(-) 0.29$ & $(-) 0.06$ & $0.60^{* *}$ & & \\
\hline
\end{tabular}

Note: *,**, and $* * *$ indicate statistical significance at 1,5 and 10 percent level.

Source: PBoC 2011b 
Table 3 Correlation results for China: Monthly data from January 2006 to December 2010

\begin{tabular}{llll} 
& Reserves & Exchange Rate & Money Supply \\
\hline Reserves & 1 & & \\
Exchange Rate & $(-) 94^{*}$ & 1 & \\
Money Supply & $0.99 *$ & $(-) 0.89 *$ & 1 \\
\hline
\end{tabular}

Note: * indicates statistical significance at 1 percent level of significance. The variables are used as monthly figures and money supply is one month lag.

Source: PBoC 2011b

Table 3A Correlation of trade with other variables in China during 2006-2010

$\begin{array}{llll}\text { Money } & \text { Reserves } & \text { Balance } & \text { Lending } \\ \text { Supply } & \text { of } & \text { Rate } \\ & & \text { Trade } & \end{array}$

\begin{tabular}{llll}
\hline Money Supply & 1 & & \\
Reserves & $0.98^{*}$ & 1 & 1 \\
Balance of Trade & $-0.91^{* * *}$ & $-0.9 * * *$ & 0.48 \\
Lending Rate & -0.52 & -0.66 & 1 \\
\hline
\end{tabular}

Note: $*$ and $* * *$ indicate statistical significance at 1 and 10 percent level. The annual figures are used for the calculation of correlation coefficients.

Source: PBoC 2011b

Table 4 Correlation Results for India from 1990-91 to 2010-11 at level form

\begin{tabular}{|c|c|c|c|c|c|c|c|c|}
\hline Variables & M3 & ER & GFD & GPD & MBCS & FDI & Portfolio & Reserves \\
\hline M3 & 1 & & & & & & & \\
\hline ER & $0.96^{*}$ & 1 & & & & & & \\
\hline GFD & $0.90 *$ & $0.76^{*}$ & 1 & & & & & \\
\hline GPF & $0.57^{*}$ & 0.35 & $0.84 *$ & 1 & & & & \\
\hline MBCS & $0.96^{*}$ & $0.85^{*}$ & $0.98 *$ & $0.5 *$ & 1 & & & \\
\hline FDI & $0.96^{*}$ & $0.93 *$ & $0.85 *$ & $0.58 *$ & $0.90^{*}$ & 1 & & \\
\hline Portfolio & $0.52 * *$ & $0.55^{* *}$ & 0.35 & 0.11 & $0.50 * *$ & $0.45^{* *}$ & 1 & \\
\hline Reserves & $0.96^{*}$ & $1.00 *$ & $0.76^{*}$ & 0.35 & $0.85^{*}$ & $0.93^{*}$ & $0.55^{* *}$ & 1 \\
\hline
\end{tabular}

Note: $*, * *$, and $* * *$ indicate the statistical significance at $1,5,10$ percent, respectively.

M3=Broad Money, ER=exchange rates, GFD=gross fiscal deficit, MBCS=market borrowing of center and state, FDI=foreign direct investment, and Portfolio=portfolio foreign investment.

Source: Government of India 2011 
Table 5 Correlation Results for India from 1990-91 to 2010-11 at log form

\begin{tabular}{|c|c|c|c|c|c|c|c|c|}
\hline Variables & M3 & ER & GFD & GPD & MBCS & FDI & Portfolio & Reserves \\
\hline M3 & 1 & & & & & & & \\
\hline ER & $0.98 *$ & 1 & & & & & & \\
\hline GFD & $0.94 *$ & $0.89 *$ & 1 & & & & & \\
\hline GPF & $0.70 *$ & $0.62 *$ & $0.81^{*}$ & 1 & & & & \\
\hline MBCS & $0.97 *$ & $0.94 *$ & $0.96 *$ & $0.70^{*}$ & 1 & & & \\
\hline FDI & $0.95^{*}$ & $0.95^{*}$ & $0.90 *$ & $0.74 *$ & $0.94 *$ & 1 & & \\
\hline Portfolio & $0.75^{*}$ & $0.80 *$ & $0.73 *$ & $50 * * *$ & $0.83 *$ & $0.84 *$ & 1 & \\
\hline Reserves & $0.98 *$ & $1.00 *$ & $0.89 *$ & $0.62 *$ & $0.96 *$ & $0.95^{*}$ & 0.8 & 1 \\
\hline
\end{tabular}

Note: $* * *$ and $* * *$ indicates the statistical significance at $1,5,10 \%$ respectively.

M3=Broad Money, ER=exchange rates, GFD=gross fiscal deficit, MBCS=market borrowing of center and state, FDI=foreign direct investment, and Portfolio=portfolio foreign investment.

Source: Government of India 2011

Table 6 Regression results using quarterly data 2000 Q1-2010 Q4

\begin{tabular}{|l|l|l|l|}
\hline $\begin{array}{l}\text { Explanatory } \\
\text { Variables }\end{array}$ & $\begin{array}{l}\text { Interest } \\
\text { Rate }\end{array}$ & Bond sales & Inflation rate \\
\hline constant & $9.4(9.88)^{*}$ & $32.43(1.14)$ & $80.42(3.04)^{*}$ \\
\hline GDP growth & & & $9.35(5.58)^{*}$ \\
\hline Growth of M3 & $\begin{array}{l}0.11 \\
(1.96)^{* *}\end{array}$ & $0.23(0.16)$ & $2.11(1.45)$ \\
\hline Bond Sales & & $-3.86(-$ & $0.22(1.75)^{*}$ \\
\hline Inflation Rate & & $2.88)^{*}$ & \\
\hline $\mathrm{R}^{2}$ & 0.09 & 0.14 & 0.46 \\
\hline F statistics & $3.84 * *$ & $4.29 * *$ & $14.64 *$ \\
\hline
\end{tabular}

Note: $*$ and $* *$ indicate the level of statistical significance at 1 percent and 5 percent, respectively. The included number of observation is 56 . The frequency of data is quarterly.

Table 6A Regression equation M3 and interest rate Interest Rate $=15.2-0.000001$ Money (M3)

\begin{tabular}{lllll}
\hline Predictor & Coef & SE Coef & T & P \\
\hline Constant & 15.1921 & 0.3005 & 50.55 & 0.000 \\
Money (M3) & -0.00000109 & 0.00000012 & -9.21 & 0.000 \\
\hline $\mathrm{S}=1.787$ & $\mathrm{R}-\mathrm{Sq}=52.1 \%$ & $\mathrm{R}-\mathrm{Sq}(\mathrm{adj})=51.5 \%$ & & \\
\hline
\end{tabular}


Table 7 Central and state government's deficit (in \% of GDP)

\begin{tabular}{llll}
\hline & $2007-08$ & $2008-09 \mathrm{BE}$ & $2009-10 \mathrm{BE}$ \\
\hline Revenue Deficit & 0.2 & 4.4 & 5.5 \\
Gross Fiscal Deficit & 4.2 & 8.9 & 10.2 \\
Gross Primary Deficit & -1.3 & 3.5 & 4.6 \\
\hline
\end{tabular}

Sources: Government of India 2010

Table 8 Major heads of expenditure: Central and state governments (in Rs crore)

\begin{tabular}{lllll}
\hline Years & $\begin{array}{l}\text { Interest } \\
\text { payments }\end{array}$ & Subsidies & $\begin{array}{l}\text { Capital } \\
\text { expenditure }\end{array}$ & $\begin{array}{l}\text { Capital Defense } \\
\text { expenditure }\end{array}$ \\
\hline $1991-92$ & 26596 & 12253 & 29122 & 4905 \\
$1992-93$ & 31075 & 10824 & 29916 & 5473 \\
$1993-94$ & 36741 & 11605 & 33684 & 6867 \\
$1994-95$ & 44060 & 11854 & 38627 & 6819 \\
$1995-96$ & 50045 & 12666 & 38414 & 8015 \\
$1996-97$ & 59478 & 15499 & 42074 & 8508 \\
$1997-98$ & 65637 & 18540 & 51718 & 9104 \\
$1998-99$ & 77882 & 23593 & 62878 & 10036 \\
$1999-00$ & 90249 & 24487 & 48975 & 11855 \\
$2000-01$ & 99314 & 26838 & 47753 & 12384 \\
$2001-02$ & 107460 & 31210 & 60842 & 16207 \\
$2002-03$ & 117804 & 43533 & 74535 & 14953 \\
$2003-04$ & 124088 & 44323 & 109129 & 16863 \\
$2004-05$ & 126934 & 45957 & 113923 & 31994 \\
$2005-06$ & 132630 & 47522 & 66362 & 32338 \\
$2006-07$ & 150272 & 57125 & 68778 & 33828 \\
$2007-08$ & 171030 & 70926 & 118238 & 37462 \\
$2008-09$ & 192694 & 129243 & 97507 & 41000 \\
$2009-10$ & 225511 & 111276 & 123606 & 54824 \\
\hline
\end{tabular}

Source: Government of India 2010 